\title{
Metode Psikoedukasi dan Mind Mapping untuk Meningkatkan Kontrol Sosial Orangtua pada Penggunaan Gadget Anak
}

\author{
Sabila Anggarawati ${ }^{1}$ \\ Fakultas Psikologi, Universitas Muhammadiyah Malang \\ e-mail: ${ }^{1}$ anggarasabila@gmail.com
}

\begin{abstract}
Social control is any process planned or unplanned, which is to investigate, encourage, even force, an individual to comply with prevailing social values. This topic is important to examine when it comes to the use of social gadgets. The lack of social control of the parents in terms of use of gadgets in children will encompass various negative impacts in terms of psychological and physical. Psychoeducation and mind mapping are selected as a method of intervention to improve parental social control in terms of use of gadgets in children. The purpose of this intervention is to improve the social control of parents on the use of child gadgets that are done with the provision of psychoeducation and mind mapping. This research is an experimental research with control group pre-test post-test design. The measuring instrument used is the social control scale. The result of the analysis using paired sample $t$ test with the result $(Z=-4,103 ; p=0,000<0,05=$ meaning there is significant difference between pretest and posttest score. It can be concluded that psychoeducation and mind mapping increase social control of parent at use of child gadgets.
\end{abstract}

KEYWORDS Mind mapping, psychoeducation, social control

CITATION Anggarawati, S. (2018). Metode psikoedukasi dan mind mapping untuk meningkatkan kontrol sosial orangtua pada penggunaan gadget anak. Cognicia, 6, (1), 38-52.

Perkembangan teknologi membuat manusia semakin mudah dalam melakukan komunikasi jarak jauh. Hal ini dikarenakan sebagian besar orang telah memiliki dan menggunakan gadget dalam kehidupan sehari-hari. Gadget merupakan suatu perangkat yang memiliki fungsi lebih spesifik, bersifat praktis dan dirancang dengan teknologi canggih. Beberapa contoh perangkat yang termasuk dalam kategori gadget adalah Laptop, MP3 Player, Smartphone, Tablet, Netbook, E-Reader, Xbook, dan Camera. Jenis gadget yang paling banyak digunakan oleh masyarakat adalah handphone atau smartphone. Menurut Menkominfo pada tahun 2014 bisa dikatakan hampir semua orang menggunakan gadget (telepon seluler), yakni sekitar 270 juta pengguna, sementara itu jumlah pengguna sambungan internet di Indonesia mencapai 47 juta pengguna.

Berdasarkan riset yang dirilis Asosiasi Penyelenggara Jasa Internet Indonesia (APJII) pada tahun 2016, lebih dari 80 persen pengguna internet di Indonesia adalah generasi muda dalam rentang usia 20-24 tahun dan 25-29 tahun. Angka tersebut relatif tinggi dibandingkan dengan penduduk pada kelompok usia lainnya. Meskipun demikian, temuan paling mengejutkan dari survei APJII ini adalah persentase 
pengguna internet pada kelompok usia 10-14 tahun yang mencapai 100 persen dengan jumlah 768 ribu. Pew Research Center (2010) menerbitkan hasil statistik yang menunjukkan bahwa hampir $80 \%$ remaja Amerika membaca blog interaktif setiap hari dan meninggalkan komentar serta menambahkan tautan di dalamnya. Tentunya hal ini akan berdampak bagi perkembangan fisik dan psikis anak-anak. Fish (2000) menyatakan bahwa content media sosial atau pemakaian internet yang terus menerus akan memberikan efek tehadap pola pikir pada remaja.

Chika (2016) dalam penelitiannya menunjukkan bahwa banyak dari mahasiswa Nigeria yang menjadi korban dari dampak negatif internet, dimana sebanyak 3.033 mahasiswa melakukan rencana pemerkosaan dan menjadi malas belajar. Hal tersebut seperti menjadi hiburan, mereka menikmati sajian content dewasa yang mudah diakses dan membuat kecanduan pada gadget. Josh (2001) mencatat bahwa tingkat kasus pemerkosaan dan kerusakan moral terjadi di kalangan masyarakat meningkat. Hal ini merupakan dampak dari banyak remaja yang diketahui telah kecanduan menggunakan gadget. Selain itu, para remaja yang baru lulus SMA di Nigeria melakukan berbagai tindak kriminal seperti mengkosumsi narkoba, pembunuhan dan perampokan. Tindakan kriminal tersebut mereka pelajari dari informasi yang didapatkan melalui internet.

Fenomena terkait juga terjadi pada anak-anak di lingkungan Kelurahan Blimbing Kota Malang. Berdasarkan hasil asesmen yang telah dilakukan, menujukkan bahwa beberapa anak mencuri-curi kesempatan untuk melihat tontonan video yang berisi content dewasa tanpa sepengetahuan orangtua. Selain itu ketika melakukan interaksi sosial langsung seperti pertemuan karang taruna, para anggota lebih sibuk dan fokus dengan gadgetnya masing-masing. Sementara itu, sebagian anak-anak juga memilih menghabiskan waktunya untuk bermain gadget atau smartphone di rumah daripada keluar dan bermain bersama teman-temannya. Anak-anak terlalu asyik bermain games dalam waktu yang lama hingga lupa waktu untuk melakukan aktivitas lainnya. Bahkan sebagian anak sudah menggunakan alat bantu penglihatan seperti kacamata karena terlalu sering melihat layar handphone. Penelitian terdahulu menunjukkan bahwa kecanduan games tidak hanya dialami oleh remaja, tetapi juga anak-anak dan orang dewasa awal (Kuss 2013). Data BBC pada tahun 2007 yang dilansir oleh Young (2009) mengungkapkan bahwa internet gaming addiction menjadi masalah kesehatan masyarakat yang serius di Cina.

Masalah tersebut terjadi karena tidak ada batasan atau aturan dari orangtua dalam menggunakan gadget. Selepas pulang sekolah, sebagian anak langsung pergi bermain tanpa diawasi oleh orangtua, dikarenakan orangtua yang sibuk bekerja. Pada akhirnya anak tersebut bermain gadget berupa smartphone atau orangtua memberikan tablet khusus bermain game agar anak tidak dapat mengakses internet. Sebagian orangtua merasa lebih aman dan nyaman ketika membiarkan anak bermain gadget di rumah daripada bermain di luar rumah yang dirasa belum tentu aman, mengingat kondisi lingkungan rumah yang dekat dengan jalan raya. Hal ini dipengaruhi oleh kurangnya kesadaran orangtua tentang pentingnya kontrol atau pengawasan terhadap penggunaan gadget pada anak.

Triwidodo \& Dewi (2012) menyatakan bahwa peneltian yang dilakukan di Universitas Maryland menunjukkan seorang dapat berubah menjadi lebih egois dan 
antisosial saat sedang menggunakan ponsel, hal ini bertentangan dengan pendapat para pengguna ponsel dan penggila jejaring sosial yang percaya ponsel dapat membuat mereka lebih mudah berkomunikasi dengan orang lain. Faktanya para pengguna jejaring sosial menjadi lebih dekat dengan orang lain di dunia maya, dan mengabaikan orang-orang yang berada di lingkungan terdekatnya. Hal ini menjadi permasalahan karena menurut teori kehadiran sosial Nuredah (2016) berpendapat komunikasi akan efektif bila memiliki media komunikasi yang sesuai dengan kehadiran sosial yang dibutuhkan untuk tingkat keterlibatan interpersonal yang diperlukan. Penelitian mengenai dampak pemakaian internet yang dilakukan oleh tim peneliti di Carnegie Mellon University menemukan bahwa pemakaian internet tinggi akan berdampak pada menurunya hubungan dengan keluarga dan meningkatnya depresi serta rasa kesepian. Internet memilki dampak buruk pada hubungan sosial bertatap muka atau langsung. Internet juga dapat menyebabkan orang mengubah hubungan sosial kuat yang dikembangkan dalam komunitas langsung dengan hubungan sosial lemah yang dibangun di lingkungan virtual.

Berdasarkan permasalahan tersebut, maka perlu adanya kesadaran akan peran orangtua dalam penggunaan gadget pada anak. Menurut Panji (2014) peran orangtua dalam pemakaian gadget pada anak sangat penting. Orangtua harus bisa mengawasi dan mengontrol atau membatasi pemakaian gadget pada anak-anak, karena dampaknya sangat serius bagi perkembangan anak-anak. Pemberian gadget pada anak harus sesuai dosis. Maksud dari dosis di sini adalah memberikan ponsel pada anak yang sesuai dengan kebutuhan anak. Jadi, orangtua cukup memberikan gadget ketika anak benar membutuhkan dan tetap dalam pantauan atau pengawasan dalam penggunaanya. Setiap keluarga mempunyai peraturan yang berbeda-beda dalam mengontrol aktivitas anak. Oleh karena itu, dibutuhkan negosiasi peraturan yang dibuat oleh orangtua dan anak. Menurut Edy (2015) orangtua melakukan peranan mereka dengan cara memberikan batas waktu dalam penggunaan internet yaitu memberikan penjelasan terlebih dahulu tentang aturan penggunaan internet yang dibatasi, hal ini berkaitan dengan waktu dan hal -hal apa saja yang dapat diakses. Orangtua tidak hanya sekedar melarang tetapi anak juga perlu tahu alasan mengapa peraturan tersebut dibuat. Setelah diberi penjelasan, maka antara orangtua dan anak membuat perjanjian mengenai penggunaan gadget.

Orangtua harus memperhatikan anak dalam penggunaan gadget agar anak tetap memiliki hubungan interaksi sosial yang baik. Monks, Knoers \& Haditono (1985) mengemukakan bahwa perkembangan sosial anak pertama kali ditanamkan oleh orangtua dalam keluarga melalui aturan-aturan, sikap dan tidakan yang dilihat oleh anak dari orangtua. Orangtua perlu melakukan kontrol sosial, Menurut Muin (2004) kontrol sosial adalah segala proses baik direncanakan maupun tidak direncanakan, yang bersifat menididik, mengajak, bahkan memaksa, suatu individu agar mematuhi kaidah-kaidah dan nilai-nilai sosial yang berlaku. Secara spesifik, social control theory menekankan adanya supervisi dan perilaku moral dapat diberikan oleh orangtua sehingga dapat mengurangi angka kenakalan. Waster, Wester (2008) mengungkapkan 500 remaja melaporkan, bahwa penyebab kenakalan dikarenakan rendahnya supervisi orangtua, tidak adanya apresiasi yang diberikan orangtua sebagai bentuk reinforment, 
dan rendahnya keterlibatan dalam aktifitas kebersamaan. Dengan demikian, orangtua perlu meningkatkan kontrol sosial kepada anak khususnya dalam hal penggunaan gadget.

Pemberian dan peningkatan kontrol sosial ini dapat dilakukan oleh orangtua dengan cara mengikuti psikoedukasi. Metode intervensi psikoedukasi sendiri terbukti efektif meningkatkan pengetahuan, pemahaman serta dapat memberikan solusi dari permasalahan yang sedang dialami oleh individu atau kelompok. Sebagaimana Karunia \& Cahyanti (2015) mengenai penelitiannya tentang pemberian psikoedukasi terhadap guru untuk anak ADHD. Hasilnya psikoedukasi mengenai ADHD terbukti berpengaruh secara signifikan terhadap kemampuan guru melakukan deteksi dini masalah ADHD pada siswa dan meningkatkan keterampilan intervensi dalam kelas. Penelitian lain yang mendukung dilakukan oleh Yulita (2013) menunjukkan psikoedukasi efektif dilakukan kepada orangtua untuk meningkatkan pengetahuan seksualitas remaja retardasi mental ringan. Psikoedukasi diberikan bertujuan untuk menambah pengetahuan dan wawasan orangtua mengenai kontrol sosial dalam pengguanan gadget pada anak.

Psikoedukasi adalah metode intervensi yang fokus mendidik partisipannya mengenai tantangan atau masalah-masalah dalam hidup. Intervensi ini dapat dilakukan pada individu, keluarga, dan kelompok, membantu partisipan mengembangkan sumber-sumber dukungan dan dukungan sosial dalam menghadapi tantangan tersebut, dan mengembangkan keterampilan coping untuk menghadapi tantangan tersebut (Walsh, 2010). Dari penjelasan di atas, dapat dikatakan psikoedukasi yang menjadi metode intervensi pada penelitian ini adalah pengetahuan dan wawasan orangtua terkait bagaimana orangtua mengontrol kegiatan anak khususnya terhadap penggunaan gadget yang tepat. Orangtua dapat mengontrol penggunaan gadget pada anak tanpa harus menghentikan dan melarang penggunaan gadget secara langsung, karena cara tersebut kurang tepat. Hal tersebut dikarenakan penggunaan gadget tidak hanya menimbulkan dampak negatif akan tetapi ada dampak positif yang dapat diperoleh anak apabila orangtua memberikan kontrol yang benar terhadap penggunaannya.

Metode intervensi yang kedua adalah mind mapping. Mind mapping akan memudahkan orangtua dalam menemukan solusi dari permasalahan yang dihadapi. Penelitian yang dilakukan Zempetakis, Leonidas A, Trionis \& Loukas (2007) menjelaskan bahwa teknik mind mapping memberikan kontribusi yang signifikan untuk belajar siswa, terutama dalam bidang pendidikan karena peta pikiran dapat mengajarkan teknik dan menghubungkan peta pikiran dengan pelajaran mereka. Penelitian lain yang mendukung, dilakukan oleh Prianti (2013) menjelaskan bahwa dengan menggunakan metode mind mapping dalam pembelajaran, siswa memperoleh nilai rata-rata yang meningkat. Mind mapping merupakan metode mencatat kreatif yang memudahkan dalam mengingat banyak informasi (Bobi DePorter, 2002). Menurut Tony Buzan (2012) dengan menggunakan teknik mind map maka akan memudahkan untuk mengingat, membuat catatan dengan lebih baik, memunculkan ide, menghemat waktu, dan berkonsentrasi. Metode yang diperkenalkan oleh Tony Buzan (2004) ini membuat bentuk penulisan catatan penuh warna dan bersifat visualisasi pengetahuan secara grafis untuk mengoptimalkan eksplorasi seluruh area 
kemampuan otak, yang bisa dikerjakan oleh satu orang atau sebuah tim yang terdiri dari beberapa orang.

Berdasarkan pemaparan di atas, dapat disimpulkan bahwa diperlukan adanya kontrol sosial orangtua kepada anak dalam hal penggunaan gadget dengan menggunakan penelitian eksperimen berupa metode intervensi psikoedukasi dan mind mapping. Tujuan peneltian ini adalah mengetahui pengaruh intervensi metode psikoedukasi dan mind mapping terhadap kontrol sosial orangtua pada penggunaan gadget anak. Manfaat teoritis dari penelitian ini diharapkan mampu mengembangkan ilmu psikologi terutama metode intervensi kelompok melalui psikoedukasi dan mind mapping tentang kontrol sosial orangtua terhadap penggunaan gadget pada anak. Selain itu, manfaat praktisnya diharapkan penelitian ini dapat diaplikasikan dalam kehidupan sehari-hari terutama bagi orangtua, dimana dapat meningkatkan kontrol sosial kepada anak dan lebih memperhatikan anak dalam penggunaan gadget. Adapun hipotesa dalam penelitian ini yaitu metode intervensi psikoedukasi dan mind mapping dapat meningkatkan kontrol sosial orangtua terhadap penggunaan gadget pada anak.

\section{METODE}

Penelitian ini menggunakan metode kuasi eksperimen. Subjek diberikan perlakuan, namun tidak menggunakan randomisasi untuk menciptakan pembandingan dalam rangka menyimpulkan perubahan yang disebabkan oleh perlakuan yang diberikan (Seniati, 2015). Desain penelitian yang digunakan dalam penelitian ini yaitu pre-test and post-test control group design, dimana pemberian pre-test dilakukan kepada kelompok kontrol dan kelompok eksperimen. Perlakuan hanya diberikan pada kelompok eksperimen, setelah itu baik kelompok kontrol maupun kelompok eksperimen diberikan post-test untuk mengetahui efek dari pemberian perlakuan pada kelompok eksperimen (Seniati, 2015). Pada penelitian ini, perlakuan yang diberikan menggunakan metode intervensi psikoedukasi dan mind mapping dengan tujuan untuk meningkatkan kontrol sosial orangtua terhadap penggunaan gadget pada anak

Tabel 1. Rancangan Penelitian

\begin{tabular}{lc}
\hline \multicolumn{1}{c}{ Kelompok } & \multicolumn{1}{c}{ Rancangan Penelitian } \\
\hline Eksperimen & $\mathrm{X} 1$--------- T --------- X2 \\
\hline Kontrol & $\mathrm{X} 1$-----------------------X2 \\
\hline
\end{tabular}

Keterangan:

$\mathrm{X} 1=$ pengukuran/pemberian skala sebelum dilakukan intervensi (Pre-test)

$\mathrm{T}=$ pemberian intervensi atau perlakuan

$\mathrm{X} 2=$ pengukuran/pemberian skala sebelum dilakukan intervensi (Post-test)

Subjek pada penelitian ini adalah ibu-ibu yang tinggal di Kelurahan Blimbing, Kota Malang. Peneliti hanya menggunakan sampel dari wilayah RW 4 dan RW 5, dimana subjek dari kedua RW tersebut akan di bagi menjadi dua kelompok yaitu kelompok kontrol dan kelompok eksperimen. Subjek dari RW 5 menjadi kelompok 
eksperimen dan subjek dari RW 4 menjadi kelompok kontrol. Adapun kriteria subjek dalam penelitian ini yaitu, (a) Ibu (b) memiliki anak usia 2 sampai 16 tahun yang bermain atau menggunakan gadget, (c) memiliki skor skala kontrol sosial rendah.

Pada penelitian ini, variabel bebas $(X)$ dan variabel terikat $(Y)$. Adapun yang menjadi variabel bebas $(X)$ yaitu intervensi psikoedukasi dengan metode psikoedukasi dan mind mapping dan variabel terikatnya $(\mathrm{Y})$ adalah kontrol sosial orangtua. Peneliti juga menggunakan variabel kontrol, yaitu penggunaan gadget pada anak. Penggunaan variabel kontrol bertujuan untuk memurnikan hasil hubungan atau pengaruh antara variabel bebas dengan variabel terikat dan dari variabel-variabel lain, selain itu juga untuk menghindari pengaruh-pengaruh variabel yang diduga mengotori hubungan antara variabel bebas dan variabel terikat (Winarsunu, 2002).

Kontrol sosial adalah cara yang digunakan orangtua untuk mengawasi atau mengontrol perilaku penggunaan gadget pada anak mereka. Pemberian kontrol sosial dalam penelitian ini dilakukan oleh orangtua khusunya ibu di wilayah RW 4 dan 5 Kelurahan Blimbing, Kota Malang. Penggunaan gadget yang berlebihan pada anak dapat mengakibatkan dampak negatif, baik secara fisik maupun psikis, oleh karena itu perlu dilakukan kontrol sosial dari orangtua atau orang terdekat.

Psikoedukasi adalah suatu bentuk perlakuan yang dilakukan peneliti berupa pemberian wawasan kepada orangtua mengenai kontrol sosial dengan model ceramah satu arah. Psikoedukasi menjelaskan mengenai pemberian kontrol sosial orangtua terhadap penggunaan gadget pada anak, kemudian dilanjutkan dengan pembuatan mind mapping yang dibimbing oleh peneliti. Mind mapping ini berfungsi untuk menganalisa dan memetakan pikiran yang dibuat dalam sebuah tulisan atau catatan kreatif yang berisi strategi atau langkah untuk mendukung pelaksanaan kontrol sosial pada anak dalam penggunaan gadget.

Dalam penelitian ini, peneliti menggunakan skala kontrol sosial. Kontrol sosial orangtua pada anak dalam penelitian ini dinilai dari hasil skor subjek penelitian dengan menggunakan skala kontrol sosial yang terdiri dari 21 aitem. Skala ini dikembangakan sendiri oleh peneliti dengan berdasar pada empat aspek, yaitu attachment, commitment, involvement, dan belief. Skala tersebut menggunakan skala Likert, dimana dengan menggunakan pilihan jawaban, antara lain : Selalu (SL), Sering (SR), Kadang-kadang (KD), dan Tidak Pernah (TP). Validitas alat ukur diukur menggunakan metode try out dengan memberikan skala Konsep Diri remaja yang tinggal di panti asuhan. Peneliti selanjutnya melakukan uji reliabilitas dan validitas menggunakan aplikasi SPSS for windows yang hasilnya ditunjukkan pada Tabel 2.

Tabel 2. Validitas dan Reliabilitas

\begin{tabular}{ccccc}
\hline & $\begin{array}{c}\text { Jumlah } \\
\text { Item yang } \\
\text { Diujikan }\end{array}$ & $\begin{array}{c}\text { Jumlah Item } \\
\text { Valid }\end{array}$ & $\begin{array}{c}\text { Indeks } \\
\text { Validitas }\end{array}$ & $\begin{array}{c}\text { Indeks } \\
\text { Reliabilitas } \\
\text { (Alpha) }\end{array}$ \\
\hline $\begin{array}{c}\text { Skala Kontrol } \\
\text { Sosial }\end{array}$ & 24 & 21 & $0,344-0,825$ & 0,919 \\
\hline
\end{tabular}


Secara umum, penelitian dan intervensi yang akan dilakukan memiliki tiga prosedur utama sebagai berikut:

Tahap pertama peneliti melakukan pengambilan data menggunakan teknik observasi dan wawancara dengan pedoman atau guide wawancara dan observasi untuk menentukan topik penelitian. Selanjutnya, peneliti melakukan pendalaman materi dan penyusunan skala penelitian mengenai kontrol sosial berdasarkan empat aspek, yaitu attachment, commitment, involvement dan belief. Peneliti kemudian memberikan skala mengenai kontrol sosial orangtua kepada 60 subjek yang digunakan sebagai try out. Setelah melakukan try out, peneliti melakukan uji kelayakan psikoedukasi dan mind mapping (simulasi) di RW 03 Kelurahan Blimbing Kota Malang. Adapun subjek yang mengikuti simulasi tersebut berjumlah 10 orang.

Peneliti meminta ijin untuk melakukan penelitian dan pemberian skala untuk memperoleh skor pre test di wilayah RW 4 dan RW 5 Kelurahan Blimbing Kota Malang. Peneliti memberikan skala kontrol sosial kepada 30 subjek yang sesuai dengan kriteria penelitian. Peneliti menyeleksi skor subjek berdasarkan norma kelompok (tinggisedang-rendah). Setelah diperoleh hasil pre-test yaitu terdapat 24 subjek yang memiliki skor kontrol sosial sedang dan rendah, sedangkan 6 subjek tereliminasi karena memiliki skor kontrol sosial tinggi. Kemudian, peneliti mengelompokkan subjek ke dalam kelompok eksperimen dan kelompok kontrol. Setelah mengelompokkan subjek, peneliti meminta kesediaan secara langsung pada kelompok eksperimen untuk dapat mengikuti kegiatan penelitian.

Tahap kedua adalah tahap intervensi, dimana subjek yang sudah terpilih akan diberikan intervensi berupa intervensi psikoeduaksi dan mind mapping. Sedangkan kelompok kontrol hanya diberikan pre-test dan post-test. Psikoedukasi dilakukan dimana peneliti menjelaskan atau memberikan materi mengenai pengaruh gadget pada anak, kontrol sosial, strategi orangtua dalam memberikan kontrol, serta materi mengenai mind mapping yang dibagi dalam beberapa sesi. Metode intervensi yang dilakukan selanjutnya adalah mind mapping. Pada kegiatan ini, peneliti tidak hanya menjelaskan materi mind mapping, namun juga membimbing subjek untuk membuat mind mapping secara langsung sesuai panduan dan arahan yang sudah dijelaskan. Tujuan dari pembuatan mind map ini adalah untuk memudahkan peserta dalam merencanakan tindakan kontrol kepada anak, dan orangtua dapat menentukan strategi kontrol yang tepat.

Tahap ketiga adalah menganalisa hasil dari keseluruhan proses intervensi. Datadata yang telah diperoleh baik hasil pre-test dan post-test diinput dan diolah dengan menggunakan program SPSS for Windows Ver. 2.1, yaitu analisis nonparametrik (subjek $<30$ ) wilcoxon untuk masing- masing kelompok. Kemudian menganalisa perbandingan pre test dan hasil post test kedua kelompok dengan menggunakan analisis mann whitney. Setelah itu peneliti membahas keseluruhan hasil analisa dengan data penunjang, yaitu hasil observasi dan wawancara. Terakhir peneliti mengambil kesimpulan penelitian.

\section{HASIL}

Setelah penelitian ini dilakukan, diperoleh beberapa hasil yang dipaparkan pada tabel-tabel berikut: Tabel 3 menunjukkan karakteristik subjek yang berpartisipasi 
dalam penelitian pengaruh metode intervensi psikoedukasi dan mind mapping terhadap kontrol sosial orangtua terhadap penggunaan gadget pada anak. Subjek yang dimaksudkan terbagi menjadi dua kelompok yaitu kelompok eksperimen dan kelompok kontrol.

Tabel 3. Karakteristik Subjek Penelitian

\begin{tabular}{|c|c|c|c|}
\hline & Kategori & $\begin{array}{l}\text { Kelompok } \\
\text { Eksperimen }\end{array}$ & Kelompok Kontrol \\
\hline Usia Anak & $\begin{array}{l}\text { Umur 2-7 tahun } \\
\text { Umur 7-11 tahun } \\
\text { Umur 11-16 tahun }\end{array}$ & $\begin{array}{l}4 \text { orang } \\
3 \text { orang } \\
5 \text { orang }\end{array}$ & $\begin{array}{l}4 \text { orang } \\
2 \text { orang } \\
6 \text { orang }\end{array}$ \\
\hline $\begin{array}{c}\text { Skor } \\
\text { Kontrol Sosial }\end{array}$ & $\begin{array}{ll}\geq 77 & \text { (Tinggi) } \\
54-76 & \text { (Sedang) } \\
<54 & \text { (Rendah) }\end{array}$ & $\begin{array}{l}- \\
10 \text { orang } \\
2 \text { orang }\end{array}$ & $\begin{array}{l}- \\
10 \text { orang } \\
2 \text { orang }\end{array}$ \\
\hline
\end{tabular}

Berdasarkan Tabel 3 tersebut, terdapat 24 ibu yang memiliki anak berusia 2-16 tahun yang menjadi subjek penelitian. Pada kelompok eksperimen terdiri dari 12 subjek dan pada kelompok kontrol terdiri dari 12 subjek. Keseluruhan subjek pada kedua kelompok baik kelompok eksperimen maupun kelompok kontrol memiliki skor kontrol sosial pada kategori rendah dan sedang. Pada masing-masing kelompok eksperimen dan kontrol terdapat 2 orang memiliki skor kontrol sosial rendah dan 10 orang memiliki skor kontrol sosial sedang. Peneliti kemudian menganalisis skor kontrol sosial pada kedua kelompok tersebut sebelum diberi perlakuan berupa psikoedukasi dan mind mapping dengan menggunakan uji Mann-Whitney untuk melihat kesetaraan kedua kelompok.

Tabel 4. Deskripsi Uji Mann Whitney Data Pre test

\begin{tabular}{cccc}
\hline Kelompok & $\mathbf{N}$ & $\mathbf{Z}$ & $\mathbf{P}$ \\
\hline Eksperimen & 12 & $-0,463$ & 0,643 \\
Kontrol & 12 & & \\
\hline
\end{tabular}

Berdasarkan hasil uji Mann Whitney di atas diperoleh hasil bahwa nilai $\mathrm{p}>0.05$ ( $p=0.643$ ), maka hal ini membuktikan bahwa tidak terdapat perbedaan skor kontrol sosial yang signifikan antara kelompok eksperimen dibandingkan kelompok kontrol. Dengan demikian dapat disimpulkan bahwa kondisi kedua kelompok dalam keadaan yang setara sebelum diberi perlakuan berupa psikoedukasi dan mind mapping pada kelompok eksperimen. Selanjutnya adalah gambaran tingkat kontrol sosial orangtua pada anak dalam penggunaan gadget pada kedua kelompok di kedua kondisi yang berbeda yaitu pre-test dan post-test.

Tabel 5. Deskripsi Uji Wilcoxon data Pre test dan Post test

\begin{tabular}{lccccc}
\hline \multirow{2}{*}{ Kelompok } & $\mathbf{N}$ & \multicolumn{2}{c}{$\begin{array}{l}\text { Rata-rata Skor } \\
\text { Kontrol Sosial }\end{array}$} & $\mathrm{Z}$ & $\mathbf{P}$ \\
\cline { 2 - 4 } & & Pre Test & Post Test & & \\
\hline Eksperimen & 12 & 11,83 & 18,42 & $-3,062$ & 0,002
\end{tabular}


Cognicia

http://ejournal.umm.ac.id/index.php/cognicia
ISSN

, Vol. , No. , -
Kontrol
12
13,17
6,58
$-1,133$
0,257

Berdasarkan hasil uji analisis Wilcoxon pada tabel 5 diperoleh hasil nilai $p<0,05$ $(\mathrm{p}=0,002)$. Hasil tersebut menunjukkan adanya perbedaan yang signifikan pada skor kontrol sosial kelompok eksperimen pada kondisi pre-test dan post-test. Sementara itu, berdasarkan hasil uji analisis Wilcoxon pada tabel deskripstif kelompok kontrol tersebut diperoleh hasil nilai $\mathrm{p}>0,05(\mathrm{p}=0,257)$. Hasil tersebut menunjukkan tidak adanya perbedaan pada skor kontrol sosial kelompok kontrol pada kondisi pre-test dan post-test.

Peneliti kemudian membandingkan skor pretest dan posttest kontrol sosial orangtua dari masing-masing subjek untuk melihat peningkatan skor masing-masing subjek. Perolehan skor kontrol sosial orangtua terhadap penggunaan gadget pada anak menunjukkan bahwa pada skor kelompok eksperimen terdapat peningkatan yang signifikan. Berikut grafik skor kontrol sosial orangtua, masing- masing subjek.

Gambar 1. Perbandingan Skor Pretest dan Posttest Skala Per-Subjek Pada Kelompok Kontrol

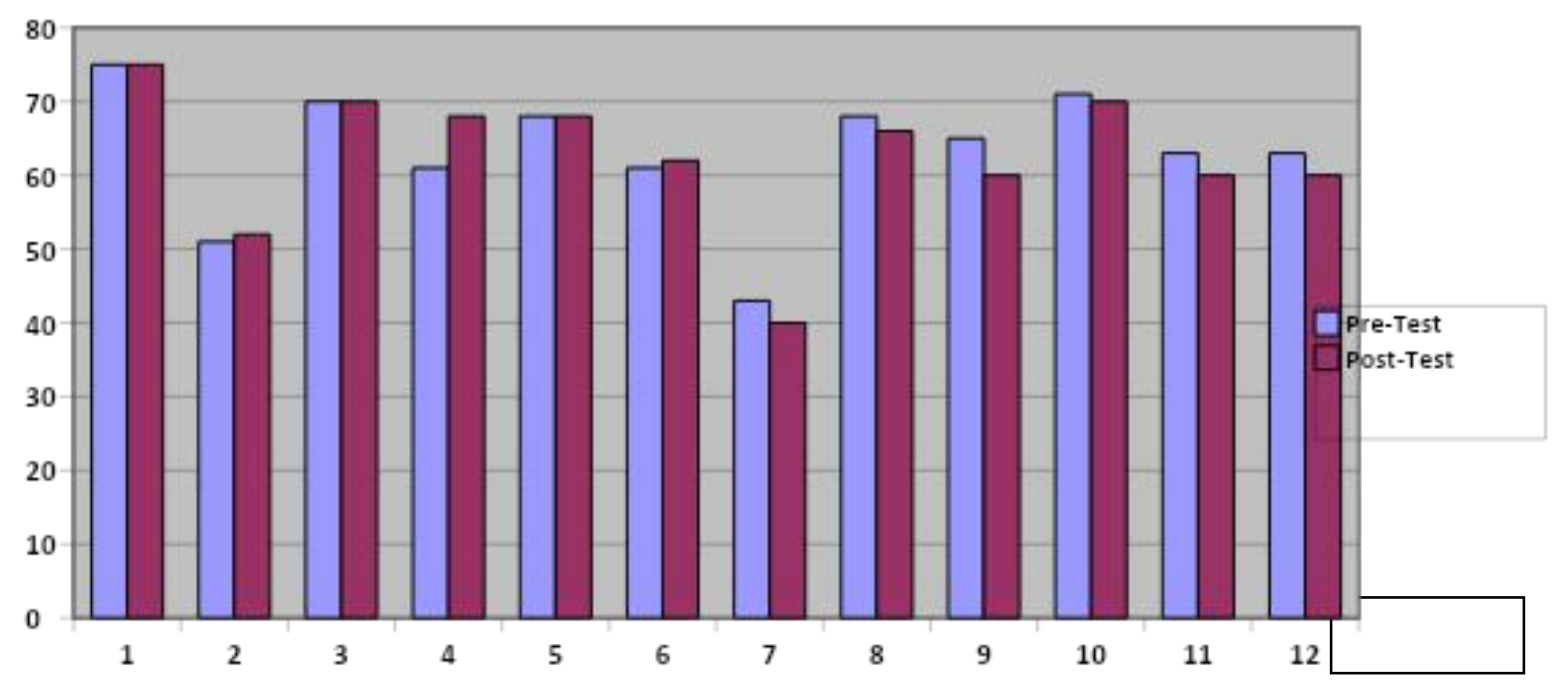

Berdasarkan gambar 1, terlihat bahwa antara skor pretest dan posttest tidak menunjukkan perbedaan yang signifikan. Secara keseluruhan hasil dari skor pretest ke posttest menunjukkan bahwa hampir semua subjek tetap dalam kategori yang sama. Diagram di atas menunjukkan bahwa kelompok kontrol atau yang tidak diberikan intervensi berupa psikoedukasi dan mind mapping tidak menunjukkan peningkatan kontrol sosial orangtua terhadap penggunaan gadget pada anak pada semua subjek.

Gambar 2. Perbandingan Skor Pretest dan Posttest Skala Per-Subjek Pada Kelompok Eksperimen 


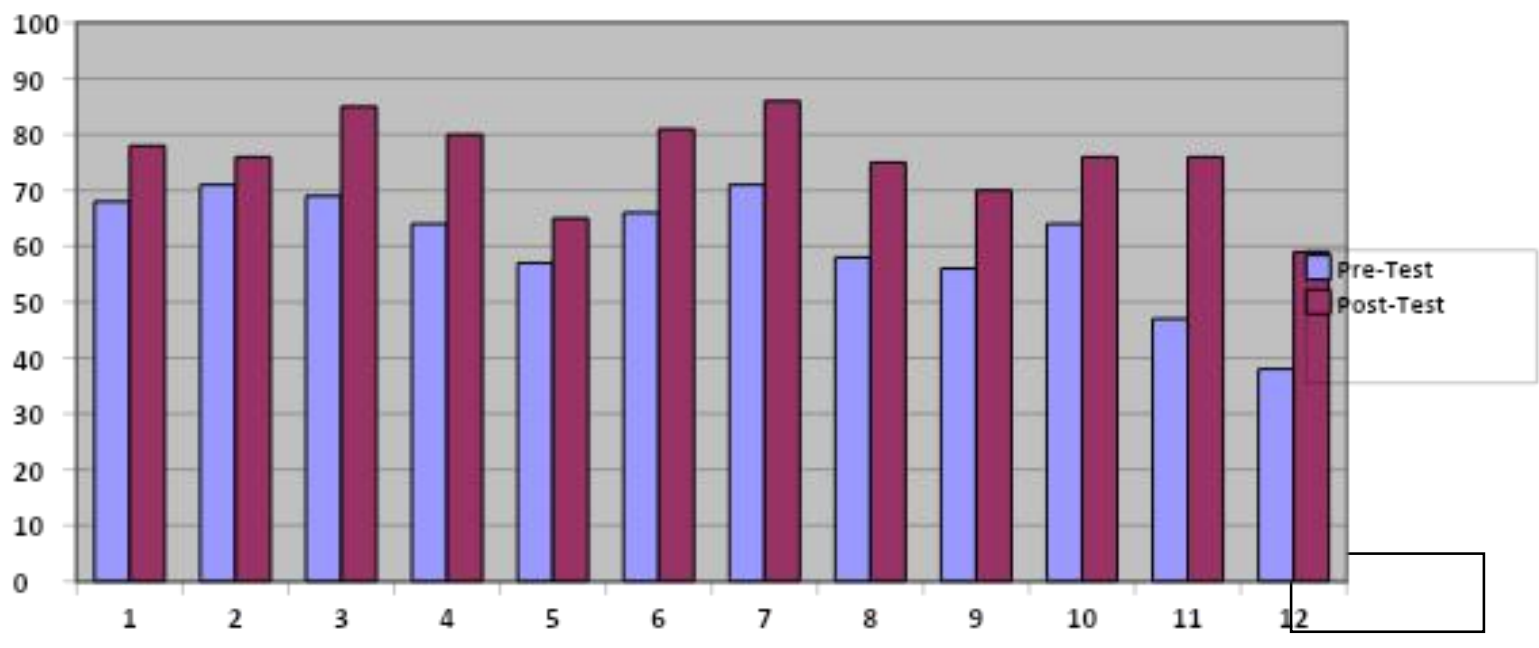

Berdasarkan gambar 2, terlihat bahwa skor post-test dari semua subjek lebih tinggi dari skor pret-test. Perbedaan tersebut menunjukkan adanya peningkatan dari skor pre-test ke skor post-test pada skala kontrol sosial. Diagram di atas menunjukkan bahwa pemberian intervensi psikoedukasi dan mind mapping dapat meningkatkan kontrol sosial orangtua terhadap penggunaan gadget pada anak. Sehingga dapat disimpulkan bahwa hipotesa penelitian diterima.

Tahap terkahir untuk hasil penelitian, peneliti melakukan analisis uji Mann Whitney untuk melihat perbedaan skor kontrol sosial kelompok eksperimen dibandingkan dengan kelompok kontrol, setelah diberikan perlakuan berupa psikoedukasi dan mand mapping. Nilai yang digunakan adalah selisih skor kontrol sosial (gain skor) saat pre-test dan post-tes. Berikut adalah tabel deskriptif hasil uji Mann Whitney.

Tabel 6. Deskripsi Uji Mann Whitney Data Gain Skor

\begin{tabular}{cccc}
\hline Kelompok & $\mathbf{N}$ & $\mathbf{Z}$ & $\mathbf{P}$ \\
\hline $\begin{array}{c}\text { Eksperimen } \\
\text { Kontrol }\end{array}$ & 12 & $-4,103$ & 0,000 \\
\hline
\end{tabular}

Berdasarkan tabel 6 Mann Whitney, merupakan nilai $\mathrm{p}<0,05(\mathrm{p}=0,000)$. Hal ini membuktikan bahwa terdapat perbedaan skor kontrol sosial yang signifikan antara kelompok eksperimen dibandingkan dengan kelompok kontrol setelah diberikan perlakuan berupa psikoedukasi dan mand mapping pada kelompok eksperimen. Dari hasil keseluruhan uji yang telah dilakukan, menunjukkan bahwa kelompok eksperimen memiliki skor kontrol sosial orangtua lebih tinggi dibandingkan kelompok kontrol terhadap penggunaan gadget pada anak.

\section{DISKUSI}

Penelitian yang telah dilakukan menunjukkan bahwa terhadapat peningkatan kemampuan kontrol sosial orangtua terhadap penggunaan gadget pada anak, khususnya para ibu di RW 5 Kelurahan Blimbing Kota Malang, setelah dilakukan 
Cognicia

http://ejournal.umm.ac.id/index.php/cognicia
ISSN

, Vol. , No.

intervensi psikoedukasi dan mind mapping. Hal ini ditunjukkan dengan nilai probabilitas yang memiliki perbedaan signifikan antara nilai pre-test dan post-test skala kontrol sosial dalam kelompok ekperimen. Hasil tersebut juga didukung oleh rata-rata skor skala kontrol sosial yang mengalami peningkatan dari pre-test ke post-test pada keseluruhan subjek. Selain itu, kemampuan kontrol sosial menunjukkan peningkatan sebanyak $67 \%$ dari total subjek. Sehingga dapat dikatakan pemberian intervensi psikoedukasi dan mind mapping dapat mempengaruhi kontrol sosial orangtua terhadap penggunaan gadget pada anak. Tingkat keberhasilan ini berdasarkan uji analisis mannwhitney dan wilcoxon pada skor pre-test dan post-test kelompok ekperimen yang menunjukkan adanya perbedaan signifikan.

Menurut Monks, Knoers \& Haditono (1985) perkembangan sosial anak pertama kali ditanamkan oleh orangtua dalam keluarga melalui aturan-aturan, sikap dan tidakan yang dilihat oleh anak dari orangtuanya. Dalam hal ini ibu memiliki peranan yang sangat penting dalam memberikan kontrol sosial kepada anak, salah satunya dalam penggunaan gadget. Menurut Harun Nasution (1995) tugas istri yang utama adalah menjadi ibu rumah tangga, yang lebih penting adalah mendidik anak-anak baik fisik maupun mentalnya. Pendidikan di rumah tangga merupakan dasar pendidikan selanjutnya ditegakkan. Dari pernyataan tersebut dapat disimpulkan peran ibu berpengaruh besar terhadap perkembangan anak.

Pada penelitian ini orangtua memberikan kontrol sosial kepada anak dalam penggunaan gadget. Pemberian penjelasan tentang bahaya atau dampak negatif dari pemakaian gadget, memberikan pemahaman bagaimana menggunakan dan memanfaatkan gadget dengan baik dan benar, adanya batasan waktu dalam pemakaian gadget, memberikan pendampingan kepada anak dalam menggunakan gadget dan memberikan pemahaman serta selektif dalam memilih aplikasi yang dapat diakses. Kontrol sosial menurut Roucek (dalam Muin 2004) merupakan segala proses baik direncanakan maupun tidak direncanakan, yang bersifat mendidik, mengajak, bahkan memaksa, suatu individu agar mematuhi kaidah-kaidah dan nilai-nilai sosial yang berlaku. Kontrol sosial sendiri telah terbukti mampu mengubah perilaku seseorang atau individu. Penelitian sebelumnya yang dilakukan oleh Hamzah (2015) menunjukkan kontrol sosial mampu mengendalikan perilaku mahasiswa kos sekitar kampus Universitas Mulawarman Samarinda.

Memberikan pemahaman mengenai kontrol sosial dapat dilakukan dengan cara psikoedukasi. Menurut Walsh (2010) psikoedukasi adalah suatu intervensi yang dapat dilakukan pada individu, keluarga, dan kelompok yang fokus pada mendidik partisipannya mengenai tantangan atau masalah dalam hidup. Lukens \& McFarlane (2004) mengatakan bahwa psikoedukasi dapat diterapkan pada berbagai setting seperti kantor, rumah sakit, perguruan tinggi, lembaga pelayanan masyarakat, militer, dan sebuah komunitas masyarakat sebagaimana yang dilakukan peneliti pada para ibu di RW 4 dan 5 Kelurahan Blimbing Kota Malang.

Jones dan Chronis (2006) menyatakan bahwa psikoedukasi tentang ADHD dapat meningkatkan pengetahuan guru tentang ADHD, meningkatkan kemampuan guru dalam mendeteksi gangguan ADHD pada siswa, serta meningkatkan keterampilan guru melakukan intervensi kelas. Pada penelitian ini menunjukkan bahwa manfaat 
dari psikoedukasi sendiri tidak hanya meningkatkan pemahaman dan menambah pengetahuan dalam suatu hal tapi mampu mengubah perilaku seseorang sesuai dengan pemahaman yang diperoleh dari psikoedukasi.

Pelaksanaan psikoedukasi dilakukan dalam beberapa sesi. Pada sesi pertama, dilakukan pemutaran video mengenai perkembangan dan dampak gadget di jaman sekarang. Pemutaran video tersebut bertujuan agar subjek memiliki pandangan awal tentang dampak dan bahaya gadget sebelum memasuki materi berikutnya. Penggunaan media video atau media audio visual ini sesuai dengan penelitian sebelumnya yang dilakukan oleh Monica (2016), menyatakan bahwa media audio visual efektif digunakan dalam kegiatan bimbingan klasikal. Setelah pemutaran video dilanjutkan dengan diskusi tentang pengalaman pribadi yang dialami oleh subjek terkait tayangan video yang telah disaksikan atau topik yang sedang dibahas yaitu dampak gadget bagi anak.

Pada sesi kedua diberikan materi tentang gadget dan perkembangan anak. Setelah berdiskusi tentang pengalaman pribadi masing-masing, peneliti memberikan materi secara singkat tentang penggunaan gadget dan tahapan perkembangan anak. Tujuan dari sesi ini untuk memberikan pemahaman terkait penggunaan gadget dan sikap serta tindakan yang perlu dilakukan sesuai dengan usia atau tahapan perkembangan anak dalam penggunaan gadget. Pada sesi ketiga peneliti memberikan materi tentang kontrol sosial orangtua. Materi tersebut merupakan materi utama, dimana subjek diberikan pemahaman dan pengetahuan tentang bagaimana memberikan kontrol sosial terhadap penggunaan gadget pada anak. Pada sesi keempat diberikan materi tentang mind mapping, dan dilanjutkan sesi kelima atau terkahir yaitu pembuatan mind mapping. Tujuan sesi ini untuk memudahkan subjek mengingat informasi dari semua materi yang didapatkan pada sesi psikoedukasi sekaligus melakukan penyusunan strategi atau langkah yang harus dilakukan orangtua untuk melakukan kontrol sosial pada anak dalam penggunaan gadget.

Pada penelitian ini psikoedukasi yang diberikan pada subjek mampu memberikan wawasan, informasi dan pengalaman-pengalaman yang dapat mereka terapkan dalam kehidupan sehari-hari. Subjek mampu mengambil pelajaran dari setiap materi yang berhubungan langsung dengan aspek kontrol sosial. Pemberian psikoedukasi pada penelitian ini disertai dengan metode mind mapping. Metode mind mapping dimaksudkan untuk mempermudah subjek dalam mengingat segala informasi yang diberikan dengan ditulis atau dicatat secara kreatif. Menurut Septiana (2007), agar pembelajaran membekas dalam ingatan peserta didik, maka diperlukan penekanan terhadap hal-hal yang telah dipelajari selama sesi kelas tersebut. Gambar atau tulisan yang menarik dan berkesan dapat membantu siswa mengingat kembali hal-hal yang telah mereka lakukan dan pelajari. Penelitian sebelumnya dilakukan oleh Immaudin \& Utomo (2012) menyatakan bahwa metode mind mapping sangat efektif dalam meningkatkan prestasi belajar fisika. Selain itu penelitian Hermawan, Kurnia \& Sudin (2016) menyatakan bahwa penerapan metode mind mapping pohon jaringan mampu meningkatkan hasil belajar siswa.

Pembuatan Mind maaping sendiri bertujuan agar subjek tidak merasa bosan dengan proses pemberian materi dalam sesi psikoedukasi namun subjek juga ikut berperan dalam menentukan strategi atau langkah yang digunakan untuk memberikan 
kontrol sosial kepada anak dalam penggunaan gadget. Hal ini sesuai pendapat Ariana (2012), yang mengatakan bahwa ketika menggunakan metode mind mapping individu tidak hanya aktif dalam suatu pelajaran atau materi namun juga dapat melihat hasil dari usaha yang telah dibuat sendiri sehingga belajar menjadi menyenangkan, penuh arti dan bermakna.

Hasil penelitian ini juga sejalan dengan penelitian yang telah dilakukan sebelumnya oleh Anny \& Rizka (2017) menunjukkan bahwa terdapat pengaruh pemberian psikoeduaksi keluarga terhadap perawatan diri toileting pada anak retardasi mental di SDLB Purwosari Kudus. Berdasarkan penjelasan di atas hal ini membuktikan bahwa psikoedukasi dan mind mapping merupakan bentuk perlakuan yang dapat digunakan untuk meningkatkan kontrol sosial orangtua terhadap penggunaan gadget anak.

Berbagai kelebihan yang telah dijelaskan sebelumnya, penelitian ini juga memilki beberapa kekurangan yaitu, waktu selama proses penelitian. Banyaknya orangtua atau ibu-ibu yang sibuk bekerja dan memilki aktivitas yang padat di rumah membuat peneliti sempat kesulitan menyesuaikan jadwal untuk mengambil data dari pre-test sampai post test. Selain itu proses pelaksanaan intervensi juga mengalami kesulitan karena banyaknya jadwal subjek yang bertabrakan namun hal ini dapat diatasi karena bantuan informasi dan komunikasi dari pengurus PKK setempat.

Pemilihan subjek dalam penelitian tidak dilakukan secara acak, dimana subjek dipilih berdasarkan kategori skor kontrol sosial sedang dan rendah. Namun, subjek dalam penelitian ini dipilih berdasarkan area atau wilayah tempat tinggal, yaitu kelompok eksperimen dari warga RW 5 dan kelompok kontrol dari warga RW 4. Hal tersebut dikarenakan karakteristik warga dan lokasi RW 4 tidak memungkinkan untuk melakukan intervensi.

\section{KESIMPULAN DAN IMPLIKASI}

Berdasarkan hasil penelitian yang telah dilakukan membuktikan bahwa pemberian metode intervensi psikoedukasi dan mind mapping merupakan bentuk perlakuan yang dapat digunakan untuk meningkatkan kontrol sosial orangtua terhadap penggunaan gadget pada anak. Implikasi dari penelitian ini diharapkan orangtua dapat memberikan dan meningkatkan kontrol sosial kepada anak dalam penggunaan gadget untuk mencengah dan meminimalisir segala dampak negatif dari gadget. Psikoedukasi dilakukan dengan cara memberikan penjelasan tentang bahaya atau dampak negatif dari penggunaan gadget, memberikan pemahaman bagaimana menggunakan dan memanfaatkan gadget secara tepat, adanya batasan waktu dalam pemakaian gadget, memberikan pendampingan kepada anak dalam menggunakan gadget dan memberikan pemahaman serta batasan jenis aplikasi yang dapat diakses. Bagi peneliti selanjutnya disarankan untuk memilih subjek yang lebih akurat dimana metode penempatan dan pemilihan masing-masing subjek dalam kelompok dilakukan secara random atau acak agar subjek yang digunakan memiliki kondisi yang sesuai dengan penelitian yang dilakukan. 
MIND MAPPING, PSYCHOEDUCATION, SOCIAL CONTROL 
Cognicia

http://ejournal.umm.ac.id/index.php/cognicia
ISSN

, Vol. , No. , -

\section{REFERENSI}

Adilla N. (2009). Pengaruh kontrol sosial tehadap perilaku bullying pelajar sekolah menengah pertama. Jurnal Kriminologi Indonesia, 5(1), 55-66

Anny, R. \& Riska. (2017). Pengaruh psikoedukasi keluarga terhadap kemampuan perawatan diri toileting pada anak retardasi mental

Aggraini, F.K. (2015). Internet gaming modern: psikopatologi budaya modern, 23(1),1-12

Ariana, M. (2012). Mind mapping and brainstorming as methods of teaching bussiness concepts in English As A Foreign Language: Academica Science Journal Psychology Series, (1)

Bordbar, M, .Faridhosseini, A, . (2010). Psychoeducation for Bipolar Mood Disorder. Jurnal: Clinical, Research, Treatment Approaches to Affective Disorders.

Booth, J.A., Farrel, A., \& Varano, S. P. (2008). Social Control, Serious Delinquency, And Risk Behavior A Gender Analysis. Crime \& Delinquency, 54, (3), 423-456

Brown, Nina, W. (2011). Psychoeducational Groups 3rd Edition: Process and Practice. New York: Routledge Taylor \& Francis Group.

Buzan, T. (2012). Buku pintar mind map. Jakarta: PT. Gramedia Pustaka Utama.

De Porter, B.\& Mike H. (2002). Quantum learning. Bandung: Kaifa

Djamarah, S.B. (2004). Pola Komunikasi Orangtua dan Anak dalam Keluarga. Bandung: CV. Pustaka Setia, hlm2-3.

Budiningsih, A. (2004). Belajar dan Pembelajaran. Penerbit Rinika Cipta, Yogyakarta.

Edy, A. (2015). Ayah edy menjawab problematika orangtua abg dan remaja. Jakarta: Noura Book Publising.

Fahriantini, E. (2016). Peranan orangtua dalam pengawasan anak pada penggunaan blackberry messenger di al azhar syifa budi samarinda. eJournal Ilmu Komunikasi, 4(4), 44-55.

Fish, B. (2000). The impact of ICT on students life. Retrieved 16 Juli 2010, www.palgrawe.com/product/title aspxPID.

Hanifah F. (2013). Hubungan kontrol sosial orangtua dengan perilaku seks pra nikah remaja Kelurahan Batang Arau Kecamatan Padang Selatan, 1,(2).

Harun, N. 1995. Islam Rasional: Gagasan dan Pemikiran. Bandung: Mizan.

Hermawan, I. Kurnia, D. \& Sudin, A. (2016) Penerapan Metode Mind Maap Pohon Jaringan Untuk Meningkatkan Hasil Belajar Siswa Pada Materi Tokoh Sejarah Kerajaan Islam di Indonesia: Jurnal Pena Ilmiah.1,(1).

Helms, D.B \& Turner, J.S (1983) Exploring child behavior. New York: Holt Rinehart and Winston

http://www.mandalamaya.com/pengertian-gadget/. Dikases 5 Desember 2017

https://www.cnnindonesia.com/teknologi/20161024161722-185-167570/pengguna-internet-diindonesia-didominasi-anak-muda/ Diakses 5 Desember 2017

http://www.ecswe.com/downloads/publications/QOCV3/Chapter4.pdfhttp://bpptik.kominfo.go. id/2014/03/10/399/Gadget-dan-interaksi-sosial-2/ Diakses 5 Desember 2017

Jansen, E., Karen., \& Markowitz. (2002). Otak Sejuta Gygabite: Buku Pintar Membangun Ingatan Super.Bandung: Kaifa

Jones, H.A. (2006). Teacher in-service training for attention deficit/hyperactivity disorder (ADHD): Influence on knowledge about ADHD use of classroom behavior management techniques and teacher stress Maryland: University of Maryland.

Josh, L. (2001). The Technological and social climate today. Retrieved 22 September 2019, www.org.no/artickler/717.html.43k.

Kron, M.D,. \& Massey, J.L., (1980). Social control and delinquent behavior: an examination of the elements of the social bond. The Sociological Quarterly, 5(1), 155-66

Kuss, D. J. (2013). Internet gaming addiction: current perspectives. Psychology Research and Behavior Management, 26, 125-137 
Lukens, E.P., \& McFarlane, W.R. (2004). Psychoeducation as evidence-based practice: consideration for practice. reasearc and policy. Journal Brief Treatment and Crisis Intervention, 4.202-225

Monks, F.J., Knoers A.M.P., \& Haditono, S.H..(1989). Psikologi Perkembangan. Yogyakarta: Gajah Mada University Press.

Monica, M. A., Susanti, D. (2016). Efektivitas bimbingan klasikal menggunakan media audiovisual untuk mengembangkan interaksi sosial peserta didik kelas viii semester ganjil di smpn 26 bandar lampung tahun pelajaran 2016/2017. Jurnal Bimbingan dan Konseling 03. Diakses tanggal 22 Januari 2018. https://ejournal.radenintan.ac.id/index.php/konseli

M.lle,. Chika \& Oduma C.,A. (2013). Social problem of addicted use of information and comunication technology (ICT) among undergraduates student of Nigerian Universities. Afican Enduactional Indices. 5 (1).

Mu'in, I. (2004). Sosiologi untuk SMA Kelas X. Jakarta: Erlangga

Nuredah. (2016). Peran orangtua penanggulangan dampak negatif handphone pada anak. skripsi. Universitas Negeri Sunankalijaga, Yogjakarta.

Purwandari N. (2011). Keluarga, Kontrol Sosial, dan Strain : Jurnal Psikologi. 8(1).

Prianti DAMM, Admatja MB \& Arhaeni AAIN (2013). Pengaruh metode mind mapping terhadap keterampilan berpikir kreatif dan preatasi belajar IPS. Jurnal Pendidikan dasar, 3.

Panji. (2014). Pentingnya pengawasan penggunaan gadget anak . Retrieved 1 Januari 2018, fromhttp://www.nurulfikri.co.id/index.php/artikel/item/334-pentingnya-pengawasanpengunaan-gadget-anak

Rachmaniah, D. (2012). Pengaruh psikoedukasi terhadap kecemasan dan coping orangtua dalam merawat anak dengan thalasemia mayor di RSU Kabupaten Tangerang Banten. Tesis, Universitas Indonesia: Jakarta

Sarwono, W.S. 2001. Psikologi remaja. Jakarta:CV.Rajawali

Santrock, J.W,. \& Yussen, S.R. (1992). Child development, 5 th ed. Dubuque,IA, Wn, C.Brown

Saleh, Andri. (2009). Kreatif mengajar dengan mind map. Bandung: Tinta Emas Publishing

Seniati, L., Yulianto, A., \& Setiadi, B.N. (2015). Psikologi eksperimen. Jakarta : Indeks.

Septiana, N. (2007). Media belajar dari sudut pandang psikologi pembelajaran. Jurnal Pendidikan Inovatif. 3,11-15.

Slameto. (2002). Belajar dan faktor-faktor yang mempengaruhinya. Edisi Revisi. Jakarta: Rineka Cipta.

Senduk, A,G. (1985). Teori perkembangan intelektual Jean Piaget. Bandung: FPS IKIP Bandung.

Suparno, P. (2003). Teori perkembangan kognitif Jean piaget. Yogyakarta: Kanisus

Triwidodo,Y., \& Dewi, KM. (2012). Loneliness Smartphone Users in Term of Gender Differences In Class X1 Students Of SMAN 9 Semarang. Jurnal Psikologi, 1, (1), 193-204

Walsh, J. (2010). Psychoeducation in Mental health. Practice, Research, and Policy Oxford University Press. Chicago: Lyceum Books, Inc.

Wester, KA., MacDonald, C.A., \& Lewis, T.F. (2008). A glimpse into the lives of nine youth in a correctional facility: Insight into theories of delinquency. Journal of Addictions \& Offender Counseling. 68.

Young, K. (2009). Understanding online gaming addiction and treatment issues for adolescents. The American Journal of Family Therapy ,26,355-372

Yulita, K. S.,(2013). Efektivitas psiokoedukasi pada orangtua dalam meningkatkan pengetahuan seksualitas remaja retardasi mental ringan. Jurnal Psikologi, 9(1).

Zempetakis, Leonidas A, Trionis. (2007). Creativity development in engineering education: the case of mind mapping. Journal of Development,26(3),370-380 